\title{
CERTIFICATION OF SEMI-FOREST COFFEE AS A LAND-SHARING STRATEGY IN ETHIOPIA
}

\author{
Fikadu Mitiku $^{\mathrm{a}, \mathrm{b}}$, Jan Nyssen $^{\mathrm{c}}$, Miet Maertens ${ }^{\mathrm{b}}$ \\ a Department of Agricultural Economics and Extension, Jimma University, Ethiopia \\ b Divisions of Bioeconomics, Department of Earth and Environmental Sciences, KU Leuven, Belgium \\ c Department of Geography, Ghent University, Belgium
}

\begin{abstract}
We analyze whether private sustainability standards can improve the economic benefits from less intensified semi-forest coffee production in southwestern Ethiopia. We compare garden and semi-forest coffee systems, including non-certified and Rainforest Alliance certified semiforest coffee, and evaluate yields, returns to land, returns to labor and profits. We use original household- and plot-level survey from 454 households and 758 coffee plots derived from a household survey and Geographic Information Systems, and ordinary least squares and fixed effects regression models. We find that more intensified garden coffee plots bring about higher yields and returns to land than less intensified semi-forest coffee plots; and that Rainforest Alliance certification of semi-forest coffee leads to higher returns to land and labor, and profits than non-certified semi-forest and garden coffee, mainly by guaranteeing farmers a better price and not by improving yields. Findings imply that in southwestern Ethiopia coffee certification can support farmers' incentives for land-sharing between coffee production and semi-natural forest conservation.
\end{abstract}

\section{Highlights}

- Static comparison of garden coffee, and certified and non-certified semi-forest coffee

- OLS and fixed effects models to control for observed and unobserved heterogeneity

- Higher economic benefits for garden coffee than for less intensified semi-forest coffee

- Rainforest Alliance certification of semi-forest coffee results in higher returns and profits

- Rainforest Alliance certification supports incentives for land-sharing

\section{Keywords}

Semi-forest coffee, Land-sharing, Rainforest Alliance, Coffee intensification, Sustainability Standards, Ethiopia 


\section{Certification of Semi-forest Coffee as a Land-sharing Strategy in Ethiopia}

\section{Introduction}

Sustainable agricultural production is a challenge. Especially in developing countries there are large trade-offs between socio-economic goals of increasing rural incomes and decreasing poverty and environmental goals such as biodiversity conservation (Bekessy et al., 2010). There is an ongoing debate on whether sustainability is best achieved through land-sharing or landsparing (Green et al., 2005, Phalan et al., 2011, Kremen and Miles, 2012, Tscharntke et al., 2012, Kremen, 2015). The first entails the integration of both biodiversity conservation and agricultural production on the same land, presuming a less intensive production system and lower yields. The latter entails intensified agricultural production with higher yields on farmland while protecting other land from agricultural encroachment and sparing it for biodiversity conservation. Some ecological studies conclude land-sparing to be most beneficial for biodiversity conservation (Phalan et al., 2011, Law et al., 2015) while others find comparable biodiversity outcomes from both strategies (Yoshii et al., 2015). Some studies have taken into account the socio-economic implications of these strategies and conclude landsharing to result in more diversified livelihoods (Dressler et al., 2016) and employment creation (Lee et al., 2014). Others argue that agricultural intensification on farmland and land-sparing for biodiversity conservation is the best option for enhancing profits and farmers' welfare (Lusiana et al., 2012). Yet, there is also doubt on the potential of land-sparing strategies to close yield gaps, and to meet the growing global food demand (Phalan et al., 2014). Agro-

forestry systems have been put forward as possible land-sharing strategies. It has been shown that low-shade agro-forestry systems can reduce trade-offs between income, biodiversity and ecosystem functioning in the process of tropical rainforest conversion and agro-forestry intensification in Indonesia (Steffan-Dewenter et al., 2007). For coffee systems in Ethiopia it has been shown that, when benefits from ecosystem functions, biodiversity conservation and carbon storage are taken into account along wit economic benefits, land-sharing between seminatural forest and coffee production is more sustainable than land-sparing for strict forest conservation with traditional forest conversion for food crop production (Reichhuber and Requate, 2012).

In this study we add on this literature with a different perspective and analyze whether certification to private sustainability standards can create the economic incentives for landsharing between coffee cultivation and semi-natural forest conservation in Ethiopia. We compare in a static way more intensified clear-cut garden coffee systems and less intensified 
semi-forest coffee systems, including non-certified and Rainforest Alliance certified semiforest coffee. We analyze the economic benefits of these systems and evaluate coffee yields, return to land, return to labor and profits. We use original household- and plot-level survey data from 454 households and 758 coffee plots in Jimma and Kaffa zones in southwestern Ethiopia. We apply ordinary least squares regression models, controlling for a large set of plot- and household-level observable characteristics, and fixed effects regression models in which household-level unobservable heterogeneity is controlled for.

The focus on coffee is particularly relevant. The debate on land-sharing versus landsparing as a sustainability strategy is especially fierce for coffee and other commodities that are grown at higher altitudes in forest marginal areas and that are vital for countries' foreign exchange earnings and for the livelihoods of a large share of the population. A number of ecological studies point to negative effects of coffee intensification on biodiversity conservation (Hundera et al., 2013a, Hundera et al., 2013b, Hylander et al., 2013). Such studies rarely take into account economic benefits and work under the assumption that coffee intensification increases productivity and farm incomes; thereby assuming a trade-off between ecological and economic goals. There are only a handful of studies taking into account yields, and sometimes costs and revenues, in evaluating the implications of coffee intensification versus land-sharing between coffee production and forest conservation. Noponen et al. (2013) confirm that coffee intensification increases profits in Costa Rica, while other studies from Mexico and Indonesia show that coffee intensification does not improve yields or economic returns (RomeroAlvarado et al., 2002, Peeters et al., 2003, Philpott et al., 2008). The effects of coffee intensification might not hold the same for Ethiopia due to the gradual process in coffee intensification and low level of external input use for coffee production.

The focus on private sustainability standards, Rainforest Alliance (RA) in particular, as a tool to promote land-sharing is relevant because private standards are spreading rapidly in many agri-food sectors, and often promise to minimize the trade-offs between food production and biodiversity conservation, and to foster more sustainable production systems (Pinto et al., 2014). For example, RA is a market based mechanism that seeks to transform agriculture into a sustainable activity that strives to conserve on-farm biodiversity and improve livelihoods (Rainforest Alliance, 2015a) - and thereby implicitly supports a land-sharing strategy. RA certification is expanding and in 2014 RA-certified farms accounted for $15.1 \%$ of world tea production, $13.6 \%$ of cocoa and 5\% of coffee production (Rainforest Alliance, 2015b). Ecological studies show that RA enhances tree cover, semi-natural forest quality and forest connectivity in semi-natural coffee forest landscapes (Takahashi and Todo, 2013, Takahashi 
and Todo, 2014, Hardt et al., 2015, Rueda et al., 2015, Takahashi and Todo, 2017). Economic studies indicate that RA certification increases yields and incomes and reduces poverty - e.g. in Nicaragua (Ruben and Zuniga, 2011) and Ethiopia (Mitiku et al., 2017). Perfecto et al. (2005) raise doubt on the beneficial impact of RA certification and argue that the price premium for certified coffee does not compensate for low yields in less intensified shade coffee systems in Mexico. Most of these economic studies on the impact of RA (and other eco-) certification, however, do not take into account the intensification gradient in coffee production systems and do not control for plot-level heterogeneity.

The focus on Ethiopia is relevant because land-sharing between coffee production and biodiversity conservation is a common practice in the Afromontane forest of southwestern Ethiopia, the birth place of Coffea arabica and known for its rich biodiversity. Nevertheless, forest thinning for coffee intensification and for conversion into other cropland is an on-going process, accounting for over $36 \%$ forest cover loss in the last four decades in the region (Aerts et al., 2013, Getahun et al., 2013, Hundera et al., 2013b, Tadesse et al., 2014). RA certification was introduced in the coffee sector in southwestern Ethiopia in 2007 to exclusively certify seminatural forest coffee production systems with a shade cover of at least $40 \%$. In this paper we investigate whether RA certification can create economic benefits and support incentives for land-sharing between less intensified coffee production and semi-natural forest conservation.

\section{Background}

\subsection{Coffee production systems in Ethiopia}

Ethiopia is the main coffee producing country in Africa and the fifth worldwide (International Coffee Organization, 2017). Coffee accounts for $24 \%$ of Ethiopia's foreign exchange earnings (Minten et al., 2014) and contributes to the livelihood of more than a quarter of the country's population (Tefera and Tefera, 2014). Over the period 1990 to 2016, coffee production increased from 2.9 million bags (with one bag equivalent to $60 \mathrm{~kg}$ ) to 6.6 million bags; and exports increased from 0.85 to 3.2 million bags (International Coffee Organization, 2017). About $95 \%$ of coffee production is realized by smallholder farmers with average landholdings below 2 ha; some of whom are organized in cooperatives (Francom and Tefera, 2016).

Coffee is produced under four different production systems, along an intensification gradient: forest coffee accounting for $10 \%$ of total coffee production; semi-forest coffee accounting for 35\%; garden coffee for 50\%; and plantation coffee for 5\% (Kufa, 2012). Forest coffee is not planted but is picked from natural coffee shrubs in less disturbed natural forests 
with no or hardly any management efforts (Hundera et al., 2013b). Semi-forest coffee is produced in relatively disturbed natural forests where the upper canopy is tinned and coffee is sometimes randomly planted in the forest to increase the number of shrubs (Gole et al., 2008). Farmers usually slash undergrowth once a year to reduce competition for soil nutrients with other species. Garden coffee is planted on small-scale agricultural plots either in monoculture with scattered shade trees or intercropped with fruit trees, spices, false banana (Enset ventricosum) and khat (Catha edulis). Coffee plantations are large-scale coffee farms established by larger private investors with modern production techniques. While forest, semiforest and garden coffee production systems have a long tradition in Ethiopia, coffee plantations are more recent. Coffee yields increase along this intensification gradient and are estimated at 50 to $150 \mathrm{~kg}$ of green coffee per ha for forest coffee, 100 to $200 \mathrm{~kg} / \mathrm{ha}$ for semi-forest coffee, 400 to $500 \mathrm{~kg} / \mathrm{ha}$ for garden coffee and $450-750 \mathrm{~kg} / \mathrm{ha}$ for plantation coffee (Wiersum et al., 2008).

In southwestern Ethiopia, coffee intensification is gradually evolving through thinning the natural unmanaged (spared) forests, where wild coffee naturally grows and producers simply pick the coffee cherries. Coffee producers intensify coffee management in the forest by opening the upper canopy, planting more coffee shrubs, slashing the undergrowth and gradually converting forest coffee to semi-forest coffee production systems. Garden coffee systems may emerge from further removal of forest trees, increasing coffee shrub density by planting coffee and increased intensify of coffee management in semi-forest coffee systems as well as from planting coffee on already cleared farmland. In general in Ethiopia, the use of inputs such as chemical fertilizers and pesticides in coffee production is very low, even in garden coffee systems. Hence, the process of coffee intensification is less associated with capital intensification, and different from the situation where shade coffee is converted into monoculture coffee plantations with high external input use, as observed in other countries.

Coffee intensification and coffee expansion are among the major responsible factors for substantial forest cover loss in Ethiopia. It has been estimated that in the last four decades in Southwestern Ethiopia, the conversion of forest coffee to semi-forest coffee resulted in a $34 \%$ reduction in woody forest species and the conversion of semi-forest coffee to garden coffee in a $37 \%$ woody forest species reduction (Tadesse et al., 2014). Coffee intensification is responsible for an important part of the forest cover loss of more than 50,000 ha between 1973 and 2009 in three zones in Southwestern Ethiopia (Tegegne, 2017).

\subsection{Rainforest Alliance coffee certification in Ethiopia}


Private sustainability standards started to emerge in the coffee sector in Ethiopia recently, starting with Fairtrade and Organic standards in 2002 and followed by Rainforest Alliance (RA) and Utz standards in 2007 (Stillmacher and Grote, 2011). Fairtrade and Organic standards are the most widespread and certify coffee without disaggregating by production system; whereas RA is less widespread and exclusively certifies forest and semi-forest coffee, defined as coffee systems with a shade cover of at least $40 \%$. RA certification was introduced in Ethiopia with the support of the Japan International Cooperation Agency (JICA) and under the auspices of the Oromia Forest and Wildlife Enterprise (OFWE) which is responsible for forest conservation and participatory forest management in the Oromia Region. In the light of RA certification, farmers with forest and semi-forest coffee are organized in small participatory forest management groups known as Waldaa Bulchiinsa Bosonaa (WaBUB) in the Oromo language (Afaan Oromoo). These farmer groups are trained by OFWE in order to produce coffee according to the criteria of the Sustainable Agriculture Network (SAN) which is required for RA certification. To become RA certified, farmers are audited against a multitude of criteria organized under 10 principles, including management system, ecosystem conservation, wildlife protection, water conservation, working conditions, occupational health, community relation, integrated crop management, soil conservation, and integrated waste management (Table A4 in appendix). The RA certificate has to be renewed every year based on rigorous inspection of individual farmers' forest and semi-forest plots.

By 2010, the number of farmers supplying RA certified coffee in Ethiopia increased to 3050 (Takahashi and Todo, 2014). RA certified farmers usually supply dried coffee cherries to OFWE, where the coffee is dry-processed into green coffee beans and directly exported. The export supply chain for RA certified coffee is shorter than for other coffee, which is mostly supplied to coffee cooperatives, from where it is transported to cooperatives unions and exported through the Ethiopian Commodity Exchange (ECX) (Mitiku et al., 2017).

\section{Data and methods}

\subsection{Research area and data collection}

We conducted this study in Jimma and Kaffa zones in southwestern Ethiopia. We collected original and unique household- and plot- level data in 2014 from a quantitative survey among 454 smallholder coffee producers; and qualitative data from semi-structured interviews with key informants in the coffee sector. A multi-stage stratified random sampling strategy was used to select smallholder coffee farmers. Four districts in the two zones were purposively selected 
based on the presence of coffee certification schemes and the extent of forest, semi-forest and garden coffee cultivation: three districts from Kaffa zone and one district from Jimma zone were selected. In all but one district, two coffee cooperatives were selected from which a list of member farmers was obtained. Due to a low number of active coffee cooperatives, in one of the selected districts only one cooperative was selected and a list of non-cooperative farmers was added to the sampling frame. Finally, coffee farmers were randomly selected from the obtained lists. The sample includes 454 coffee farmers of which 81 are RA certified. From these farmers, we obtained detailed plot-level data for all coffee plots, resulting in information from 758 coffee plots, including 399 garden coffee plots and 359 semi-forest coffee plots. The latter include 156 RA certified plots (RA plots) and 203 non-RA certified plots (NRA plots).

The survey was implemented in the period January-March 2014, using a structured questionnaire with modules on household characteristics, land ownership and land use, coffee production and marketing, crop production, livestock ownership and production, forest and farm households interaction, off-farm income, asset ownership and living conditions, and social capital. Detailed data were collected for the 12-months period prior to the survey such that data on production and marketing of coffee and other crops related to the 2013/14 season were obtained. Plot coordinates and elevations were collected using GPS devices. The survey was implemented in the field with a team of enumerators, most of whom are from the study region and hold at least a bachelor degree, and survey coordinators. Standard survey procedures, including pre-testing of the questionnaire in the field and intensive enumerator training, were followed. The survey was implemented in local languages, Amharic, Afaan Oromoo or Kafinoono and households were interviewed in a quiet place in order to avoid interruption during the interview. Completed questionnaires were checked daily by the researchers and survey coordinators, and households revisited in case of incompleteness, inconsistencies or lack of clarity.

Household survey data were complemented with information from semi-structured interviews with cooperative committees, district officials and officials from the coffee unions. Data on coffee prices and information on RA premiums and secondary payments were also collected from cooperatives. 


\subsection{Outcome indicators}

In our analysis we focus on four outcome indicators: coffee yield, return to land, return to labor and profit. We are mainly interested in comparing these outcome indicators for garden and semi-forest coffee, and certified and non-certified coffee but we also take into account that farmers cultivate a variety of seasonal food crops such as maize, teff and beans in additional to coffee. We calculate the outcome indicators for four categories of plots: garden plots including coffee and seasonal crops (GRDSC); garden coffee plots (GRD); RA-certified semi-forest coffee plots (RA); and non-certified semi-forest coffee plots (NRA). RA and NRA plots are semi-forest plots including coffee shrubs scattered within the forest and include the whole area of the semi-forest plot. GRDSC plots refer to farmland including coffee as well as seasonal food crops planted next to each other (usually not intercropped) while GRD plots refer to only that part of the farmland that is planted with coffee. Coffee yields are only calculated for GRD, RA and NRA plots while returns to land, returns to labor and profits are calculated for all plots.

Coffee yield is calculated as the ratio of dry coffee cherry equivalent to the plot area, and expressed in $\mathrm{kg}$ per ha. Return to land is calculated as the ratio of net income from coffee (GRD, RA and NRA plots) or net income from coffee and seasonal crops (GRDSC plots) to the plot area, and expressed in Ethiopian Birr (ETB) per ha. Net income from coffee and seasonal crops is calculated as the total revenue from coffee and seasonal crop production (with sales and own consumption valued at market prices) minus variable costs of production and marketing, including costs of hired labor and including cost of certification ${ }^{1}$ for RA plots. Return to labor is calculated as the ratio of net income from coffee (GRD, RA and NRA plots) or net income from coffee and seasonal crops (GRDSC plots) to the number of man-days (MD) of family labor used in production and processing, and expressed in ETB per MD. Profit is calculated as the ratio of net income from coffee (GRD, RA and NRA plots) or net income from coffee and seasonal crops (GRDSC plots) minus the opportunity costs of family labor in production and processing to the area, and expressed in ETB per ha. Family labor is valued at the national minimum wage - which is justified given the very limited off-farm employment opportunities in the research area.

The return to and profit from semi-forest coffee plots are slightly underestimated as benefits from other forest products such as timber, wild honey, spices and medicines are not accounted for (due to a lack of data). Yet, this underestimation is only marginal, given that the

\footnotetext{
${ }^{1}$ The main certification and certificate renewal cost is paid at cooperative level, however, a household pays 10 ETB for the inspection of coffee plots by an internal control committee.
} 
contribution of these forest products to household income is estimated to be less than $1 \%$ (Mitiku et al., 2017). This implies that also benefits from thinning and clearing semi-forest in terms of wood removal are not accounted for. Given that (semi-)forest is usually gradually thinned and converted because the participatory forest management protects (semi-)forest and does not allow clear-cutting, it is not possible to capture these benefits in our static approach.

\subsection{Descriptive and econometric analysis}

We describe relevant household- and plot-level variables, making a distinction between certified and non-certified households, and between different type of plots. To compare garden and semi-forest coffee plots and reveal the impact of coffee certification, we use different econometric models estimated at the plot level. First, we estimate the following linear regression models:

$$
Y_{i j}=\alpha+\partial N R A_{i j}+\gamma R A_{i j}+\delta P_{i j}+\tau X_{j}+a_{j}+\mu_{i j}
$$

Regressions are estimated separately for each of the four outcome variables $Y_{i j}$ : coffee yield, return to land, return to labor and profits for plot $i$ and household $j$. The main variables of interest in equation (1) are $N R A_{i j}$ and $R A_{i j}$, binary variables indicating whether a plot is a semiforest non-certified plot $\left(N R A_{i j}=1\right)$ respectively a semi-forest RA-certified plot $\left(R A_{i j}=1\right)$. The estimated parameters $\partial$ and $\gamma$ capture the differences in yield, return to land, return to labor and profits between garden coffee on the one hand and non-certified and RA-certified semiforest coffee plots on the other hand. These parameters reveal differences in economic benefits between more intensified garden coffee and less intensified semi-forest coffee, while a comparison of these parameters allows to discuss the impact of coffee certification. To control for observed heterogeneity, the models include a first vector of control variables $P_{i j}$ representing plot-level agro-ecological and other characteristics that may influence the outcome variables. The vector includes the coffee area (in ha), the age of coffee shrubs (years), soil type (binary variables for Humic Nitisols, Humic Alisols and Lithic Leptosols), slope (degrees), distance from a road $(\mathrm{m})$, distance from the cooperative $(\mathrm{m})$, distance from a river $(\mathrm{m})$, and elevation $(\mathrm{m})$. The age of the coffee shrubs is revealed from the household survey data while all other plot-level characteristics are derived from GPS coordinates and GIS information. A second vector of control variables $X_{j}$ represents human, physical and social capital indicators at the household level: age, gender and education of the household head, number of workers and number of dependents in the household, number of livestock units owned (in TLU) and the number of relatives in the region. The models include a composite error term comprising a 
household specific component $a_{j}$ and a plot specific component $\mu_{i j}$. The models are estimated using ordinary least squares (OLS) and heteroskedasticity-robust standard errors are reported. The estimated parameters $\partial$ and $\gamma$ in equation (1) are compared using a post-estimation F-test.

Second, we estimate the fixed effects (FE) models specified in equations (2) and (3). While including a large number of plot- and household-level control variables in model (1), the estimates might still suffer from bias related to unobserved heterogeneity being correlated with coffee certification and the outcome variables. To control for unobserved heterogeneity at the household level, we exploit the fact that a substantial share of households in the sample have both a garden and a semi-forest (either non-certified or RA-certified) plot and apply a panel fixed effects (FE) approach with plot (instead of time) demeaned data - an approach suggested by Barrett et al. (2004) and applied by Minten et al. (2007) and Reira and Swinnen (2016). In the FE model (2), we use a subsample $\mathrm{N}_{1}$ of 54 households owning at least one garden (GRD) and at least one RA-certified semi-forest (RA) plot, and perform a FE transformation with plotdemeaned data ${ }^{2}$. Likewise, in model (3) we do a FE transformation on a subsample $\mathrm{N}_{2}$ of 58 households owning at least one garden (GRD) and one non-certified semi-forest (NRA) plot.

$$
\begin{aligned}
& \ddot{Y}_{\mathrm{ij}}=\gamma^{\prime} \ddot{\mathrm{RA}}_{\mathrm{ij}}+\delta \ddot{\mathrm{P}}_{\mathrm{ij}}+\ddot{\varepsilon}_{\mathrm{ij}} ; \forall j \in N_{1} \\
& \ddot{Y}_{i j}=\partial^{\prime} \mathrm{N} \ddot{\mathrm{R}} \mathrm{A}_{\mathrm{ij}}+\delta \ddot{P}_{i j}+\ddot{v}_{i j} ; \forall j \in N_{2}
\end{aligned}
$$

The estimated parameters $\gamma^{\prime}$ and $\partial^{\prime}$ capture within household differences in coffee yield, return to land, return to labor and profitability, respectively between garden coffee and RA-certified semi-forest coffee, and between garden coffee and NRA-certified semi-forest coffee. These can be interpreted as differences in economic benefits between more intensified and less intensified coffee systems, while a comparison of these parameters reveals something about the impact of coffee certification. In these models plot-constant household-level heterogeneity, e.g. stemming from unobserved differences in farmers' ability, entrepreneurship and motivation, is ruled out. Plot-level unobserved heterogeneity cannot be ruled out completely but is likely very limited, given that we control for a large number of observed plot-level characteristics.

\section{Results}

\subsection{Certified and non-certified households}

Table 1 presents summary statistics for household characteristics and compares these among non-certified and RA-certified households. The level of education in the research area is very

\footnotetext{
${ }^{2}$ For the fixed effects models we used the xtreg command in STATA 14, which automatically computes variable means, subtracts the means from the original variables, and runs a regression on the demeaned variables.
} 
low with on average 3.7 years of schooling of the household head. Total farm size is on average 2.9 ha of which on average one third is allocated to coffee production. Statistics show that RAcertified households are slightly younger than non-certified households, and own less land and livestock. They are more specialized in coffee production than non-certified households; they allocate on average $64 \%$ of their land to coffee and have more semi-forest coffee plots.

Table 1: Mean human, physical and social capital indicators for households without certified coffee plots (NRA households) and households with Rainforest Alliance certified coffee plots (RA households)

\begin{tabular}{|c|c|c|c|c|c|c|}
\hline \multirow{2}{*}{$\begin{array}{l}\text { Variables } \\
\text { Human capital }\end{array}$} & \multicolumn{2}{|c|}{$\begin{array}{c}\begin{array}{c}\text { Total sample } \\
(\mathrm{n}=\mathbf{4 5 4})\end{array} \\
\end{array}$} & \multirow{2}{*}{\multicolumn{2}{|c|}{$\begin{array}{c}\text { NRA households } \\
(\mathrm{n}=373)\end{array}$}} & \multicolumn{2}{|c|}{$\begin{array}{c}\text { RA households } \\
(\mathrm{n}=81)\end{array}$} \\
\hline & & & & & & \\
\hline Female-headed household (\%) & 7 & & 8 & & 5 & \\
\hline Age of household head (years) & 45.33 & $(0.67)$ & 46.32 & $(0.75)$ & $\begin{array}{c}40.78 * * \\
*\end{array}$ & $(1.43)$ \\
\hline Education of household head (year) & 3.67 & $(0.16)$ & 3.67 & $(0.19)$ & 3.64 & $(0.32)$ \\
\hline Number of workers ${ }^{1}$ & 3.38 & $(0.07)$ & 3.42 & $(0.08)$ & 3.19 & (0.18) \\
\hline Number of dependents ${ }^{1}$ & 3.48 & $(0.10)$ & 3.49 & $(0.11)$ & 3.43 & $(0.25)$ \\
\hline \multicolumn{7}{|l|}{ Physical capital } \\
\hline Total farm area (ha) & 2.93 & $(0.13)$ & 3.01 & $(0.15)$ & $2.52 *$ & $(0.18)$ \\
\hline Coffee area (ha) & 0.97 & $(0.06)$ & 0.83 & $(0.06)$ & $1.61 * * *$ & $(0.15)$ \\
\hline Number of semi-forest plots & 0.79 & $(0.04)$ & 0.54 & $(0.04)$ & $1.93 * * *$ & $(0.10)$ \\
\hline Number of garden plots & 0.88 & $(0.03)$ & 0.91 & $(0.04)$ & 0.74 & $(0.07)$ \\
\hline Livestock ownership (TLU²) & 4.47 & $(0.17)$ & 4.86 & $(0.32)$ & $2.70 * * *$ & $(0.32)$ \\
\hline \multicolumn{7}{|l|}{ Social capital } \\
\hline Number of relatives in the region & 48.56 & $(3.92)$ & 49.53 & $(4.60)$ & 44.07 & $(55.87)$ \\
\hline
\end{tabular}

${ }^{1}$ Workers are household members in the age category 15 to 64 while dependents are household members in the age categories below 15 and above 64 .

${ }^{2}$ Livestock ownership is measured in Tropical Livestock Units (TLU), assigning a weight of 0.7 for cattle and mule, 0.8 for horse, 0.5 for donkey, 0.1 for sheep and goat, and 0.01 for chicken.

Standard errors in italic in parentheses. ${ }^{*} \mathrm{p}<0.1,{ }^{* *} \mathrm{p}<0.05$, and ${ }^{* * *} \mathrm{p}<0.01$ indicate significance levels for a twosided t-test on the mean differences between non-certified and RA-certified households.

Source: Authors' calculation based on household survey and GIS data 


\subsection{Garden and semi-forest certified and non-certified plots}

Table 2 presents summary statistics for agro-ecological and physical plot characteristics and compares these for garden, RA-certified and non-certified semi-forest coffee plots. Plots have mostly Humic Nitisols (91.6\%), an average slope of 9 degrees, an average elevation of 1,797 meter above sea level, and are located at $3.3 \mathrm{~km}$ from a river, $2.4 \mathrm{~km}$ from a road and $2.1 \mathrm{~km}$ from the coffee cooperative on average. Semi-forest plots are slightly steeper than garden plots and are located a bit closer to rivers and roads but further from cooperatives. Especially RAcertified semi-forest plots are steeper and located at a higher altitude than garden plots while non-certified semi-forest plots are located at a slightly lower altitude than garden plots. RAcertified semi-forest plots are more likely to have Humic Alisols than garden and non-certified semi-forest plots, and are located further from rivers and cooperatives than these plots.

Table 2: Agro-ecological and physical characteristics of garden coffee plots (GRD), Rainforest Alliance certified (RA) and non-certified (NRA) semi-forest coffee plots

\begin{tabular}{|c|c|c|c|c|c|c|c|c|}
\hline Variables & \multicolumn{2}{|c|}{$\begin{array}{c}\text { Overall mean } \\
(\mathrm{n}=758)\end{array}$} & \multicolumn{2}{|c|}{$\begin{array}{c}\text { GRD } \\
(\mathbf{n}=399)\end{array}$} & \multicolumn{2}{|c|}{$\begin{array}{c}\text { RA } \\
(\mathbf{n}=156)\end{array}$} & \multicolumn{2}{|c|}{$\begin{array}{c}\text { NRA } \\
(n=203)\end{array}$} \\
\hline Humic Nitisols (\%) & 91.6 & & 92 & & $87 *$ & & $94.6^{\mathrm{b}}$ & \\
\hline Humic Alisols (\%) & 6.6 & & 5 & & $13 * * *$ & & $4.9^{c}$ & \\
\hline Lithic Lepthosols (\%) & 1.8 & & 3 & & 0 & & 0.5 & \\
\hline Slope (degree) & 9.10 & $(0.18)$ & 8.42 & $(0.24)$ & $11.49 * * *$ & $(0.46)$ & $8.60^{\mathrm{c}}$ & $(0.31)$ \\
\hline Altitude (m.a.s.l) & 1,797 & $(5.26)$ & 1,797 & (7.29) & $1,847 * * *$ & (10.1) & $1,759^{* * *_{c}}$ & (9.74) \\
\hline Distance to river (m) & 3,269 & (63.9) & 3,354 & (94.7) & $4,006 * * *$ & (129) & $2,533^{* * *_{c}}$ & (89) \\
\hline Distance to road (m) & 2,446 & (123) & 2,629 & (198) & 2,123 & $(140)$ & 2,334 & (226) \\
\hline Distance to coop (m) & 2,157 & (68) & 1,924 & (107) & $2,686 * * *$ & (145) & $2,208^{* * *_{c}}$ & (99.9) \\
\hline
\end{tabular}

Standard errors in italic in parenthesis. ${ }^{*} \mathrm{p}<0.1,{ }^{* *} \mathrm{p}<0.05$, and ${ }^{* * *} \mathrm{p}<0.01$ indicate significance levels for a twosided t-test on mean differences between GRD plots and respectively RA and NRA plots. ${ }^{\mathrm{a}} \mathrm{p}<0.1,{ }^{\mathrm{b}} \mathrm{p}<0.05$ and ${ }^{\mathrm{c}}$ $\mathrm{p}<0.01$ indicate significance levels for a two-sided t-test on mean differences between RA and NRA plots. Plot characteristics are determined based on SRTM data (Shuttle Radar Topography Mission (SRTM) void filled 1 arcsecond global elevation data ( 30 m) available at https://earthexplorer.usgs.gov/ accessed 13 June 2016.

Source: Authors' calculation based on household survey and GIS data

Table 3 presents summary statistics of inputs into coffee production and coffee prices, and compares these for garden, certified and non-certified semi-forest coffee plots. The average coffee area is 0.84 ha and is significantly larger for semi-forest, RA-certified as well as noncertified, coffee plots than for garden coffee plots. The average age of the coffee shrubs is 15.6 years and shrubs on semi-forest plots, RA certified as well as non-certified plots, are significantly older than on garden plots.

Table 3: Inputs into coffee production and coffee prices for garden coffee (GRD), Rainforest Alliance certified (RA) and non-certified (NRA) semi-forest coffee plots 


\begin{tabular}{lcccccccc}
\hline Variables & \multicolumn{2}{c}{$\begin{array}{c}\text { Overall mean } \\
(\mathbf{n}=\mathbf{7 5 8}\end{array}$} & \multicolumn{2}{c}{$\begin{array}{c}\text { GRD plots } \\
(\mathbf{n}=\mathbf{3 9 9})\end{array}$} & \multicolumn{2}{c}{$\begin{array}{c}\text { RA plots } \\
(\mathbf{n}=\mathbf{1 5 6})\end{array}$} & \multicolumn{2}{c}{$\begin{array}{c}\text { NRA plots } \\
(\mathbf{n}=\mathbf{2 0 3})\end{array}$} \\
\hline Coffee area (ha) & 0.84 & $(0.04)$ & 0.41 & $(0.03)$ & $0.87^{* * * *}$ & $(0.09)$ & $1.66^{* * * *_{c}}$ & $(0.12)$ \\
Age of coffee shrubs (years) & 15.65 & $(0.53)$ & 11.8 & $(0.51)$ & $21.9^{* * *}$ & $(1.28)$ & $18.3^{* * *}$ & $(1.29)$ \\
Coffee shrubs per ha & 3,834 & $(201.3)$ & 4,774 & $(356)$ & $3,577^{* *}$ & $(255)$ & $2,188^{* * * c}$ & $(129)$ \\
Family labor (man-day/ha) & 215.5 & $(24)$ & 305.9 & $(41.3)$ & $115.8^{* * *}$ & $(18.5)$ & $114.5^{* * *}$ & $(33)$ \\
Cost for hired labor (ETB/ha) & 740.5 & $(245.6)$ & 966.9 & $(463)$ & 688 & $(93.7)$ & $336^{c}$ & $(83.3)$ \\
Capital costs $^{1}$ (ETB/ha) & 102.6 & $(18.6)$ & 130.8 & $(32.1)$ & 73.5 & $(18.9)$ & 69.5 & $(25.4)$ \\
Coffee price $^{2}$ (ETB/kg) & 15.73 & $(0.15)$ & 14.92 & $(0.18)$ & $18.3^{* * *}$ & $(0.38)$ & $15.3^{c}$ & $(0.26)$ \\
\hline
\end{tabular}

${ }^{1}$ Capital cost includes costs such as plot audit cost for RA plots, seedling costs, and marketing costs such as transportation cost.

${ }^{2}$ Information on coffee prices were collected for each coffee plot as semi-forest and garden coffee is usually supplied separately - but it is possible that households mix coffee from different type of plots.

Standard errors italic and parenthesis. ${ }^{*} p<0.1,{ }^{* *} p<0.05$, and ${ }^{* * *} p<0.01$ indicate significance levels for a two-sided $\mathrm{t}$-test on mean differences between GRD plots and respectively RA and NRA plots. ${ }^{\mathrm{a}} \mathrm{p}<0.1,{ }^{\mathrm{b}} \mathrm{p}<0.05$ and ${ }^{\mathrm{c}} \mathrm{p}<0.01$ indicate significance levels for a two-sided t-test on mean differences between RA and NRA plots.

Source: Authors' calculation based on household survey data

The figures show that garden coffee plots are cultivated more intensively than semiforest plots, RA certified as well as non-certified plots, with significantly higher coffee shrub density, significantly higher family labor input and higher cost of hired labor and capital although the latter differences are statistically not significant. In addition, RA-certified semiforest coffee plots are to some extent cultivated more intensively than non-certified semi-forest coffee plots, with a significantly higher coffee shrub density and higher cost of hired labor. In general in the research area, most labor input into coffee production comes from family labor and capital costs are rather low as the use of external inputs in coffee production is very limited. Coffee prices are significantly higher for RA-certified semi-forest coffee than for garden coffee and non-certified semi-forest coffee, 18.3 ETB/kg compared to $14.9 \mathrm{ETB} / \mathrm{kg}$ on average. There is no difference in price for non-certified semi-forest coffee and garden coffee plots.

In general, the use of chemical fertilizer, pesticides and herbicides is extremely low in the research area but farmers apply animal manure (41\%) and compost (18\%). Farmers use manual soil tillage (34\%), slash the undergrowth (72\%), use manual weed control (84\%), and use cultural and biological disease (46\%) and pest control (35\%) on their coffee plots. Figure 1 shows that almost all these management practices are more common in garden coffee plots than in both certified and non-certified semi-forest coffee plots. Differences are significant $(\mathrm{p}<$ 0.01), except for slashing undergrowth (no significant differences) and pest management (no significant difference between GRD and NRA plots). There are also differences between noncertified and RA-certified semi-forest coffee plots with non-certified plots being more 
intensively tilled ( $\mathrm{p}<0.01$ ), fertilized (organically) ( $\mathrm{p}<0.01$ ), and protected against diseases and pests $(\mathrm{p}<0.01)$ than RA-certified semi-forest plots.
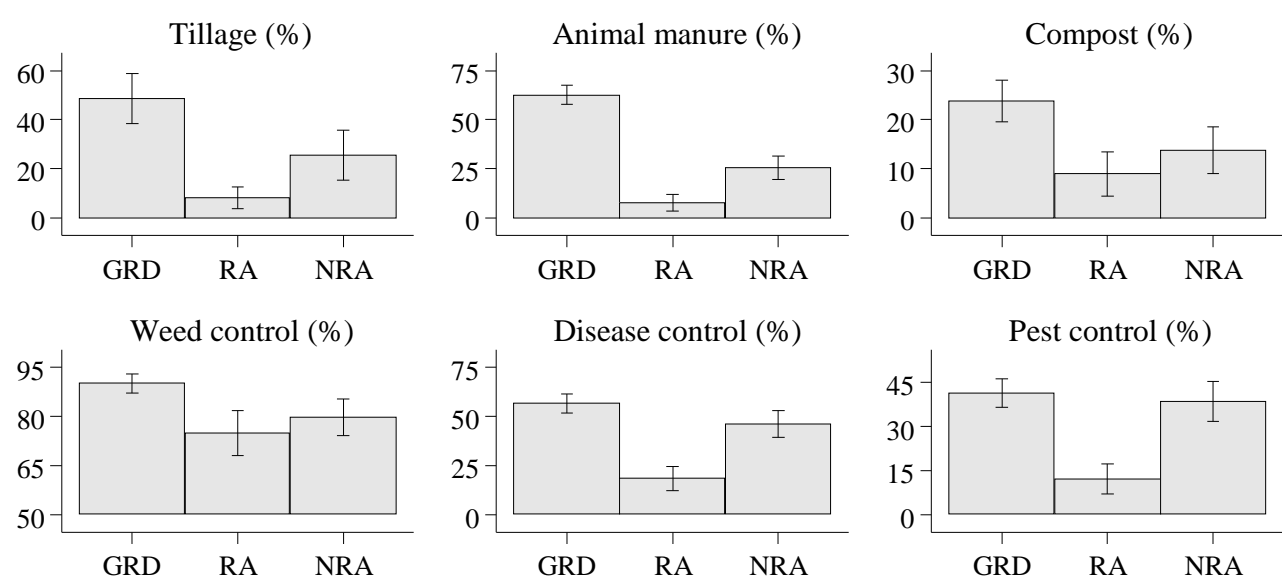

Slash undergrowth $(\%)$

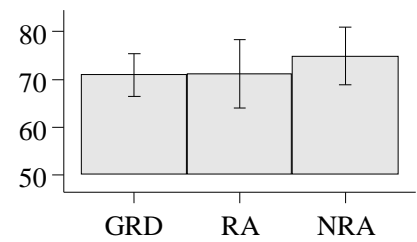

Figure 1: Use of coffee management practices on garden coffee (GRD), Rainforest Alliance certified semi-forest coffee plots (RA) and non-certified semi-forest coffee plots (NRA). Error bars represent 95\% confidence interval. Source: Authors' calculation based on household survey data.

Despite the static comparison, the figures in Table 3 and Figure 1 document the specific coffee intensification process in the research area with higher labor intensity but not necessarily higher capital intensity. Being an area where land is becoming more scare and labor more abundant, coffee intensification in the area is based on replacing land for labor and a higher per ha labor input. Farmers use very low chemical inputs such as inorganic fertilizer, herbicides and pesticides, and capital costs are very low. Coffee intensification rather implies increasing coffee shrub density and replacing land for labor by using more family (and hired) labor to till the plots, to apply animal manure and compost, and to control weed and diseases.

\subsection{Productivity, returns and profitability}

Figure 2 presents summary statistics on coffee yields for three types of coffee plots (GRD, RA and NRA), and on returns to land and labor and profits for four types of plots (GRDSC, GRD, RA and NRA). Coffee yield in dry cherry equivalent is $695 \mathrm{~kg} / \mathrm{ha}$ on average with no significant differences between garden coffee plots ( $858 \mathrm{~kg} / \mathrm{ha})$ and RA-certified semi-forest coffee plots 
$(669 \mathrm{~kg} / \mathrm{ha})$ but with yields on non-certified semi-forest coffee plots being significantly lower $(393 \mathrm{~kg} / \mathrm{ha}, \mathrm{p}<0.01)$ than on garden coffee plots and RA-certified semi-forest plots. On average, the return to land is $8,871 \mathrm{ETB} /$ ha with no significant difference between garden coffee plots (10,751 ETB/ha) and RA-certified semi-forest plots (11,455 ETB/ha). Yet, the return to land on garden plots including both coffee and seasonal crops is significantly lower (7,298 ETB/ha, $\mathrm{p}<0.01)$; the same holds for non-certified semi-forest plots $(5,672 \mathrm{ETB} / \mathrm{ha}, \mathrm{p}<0.01)$. The average return to labor is $188 \mathrm{ETB} /$ man-day with the highest return to labor on garden plots including coffee and seasonal crops (272 ETB/man-day) and a significantly lower return to labor on garden coffee plots (121 ETB/man-day, $\mathrm{p}<0.01)$. The return to labor on RA-certified and non-certified semi-forest coffee plots is lower than on garden plots (213 ETB/man-day respectively $169 \mathrm{ETB} / \mathrm{man}$-day) but differences are not significant. The average profit is 5,107 ETB/ha with the highest profit on RA-certified semi-forest plots $(9,139 \mathrm{ETB} / \mathrm{ha})$ and significantly lower profits on all other plots (3,908 ETB/ha, 5,370 ETB/ha and 3,383 ETB/ha on respectively GRDSC, RA and NRA plots, $\mathrm{p}<0.01$ ).
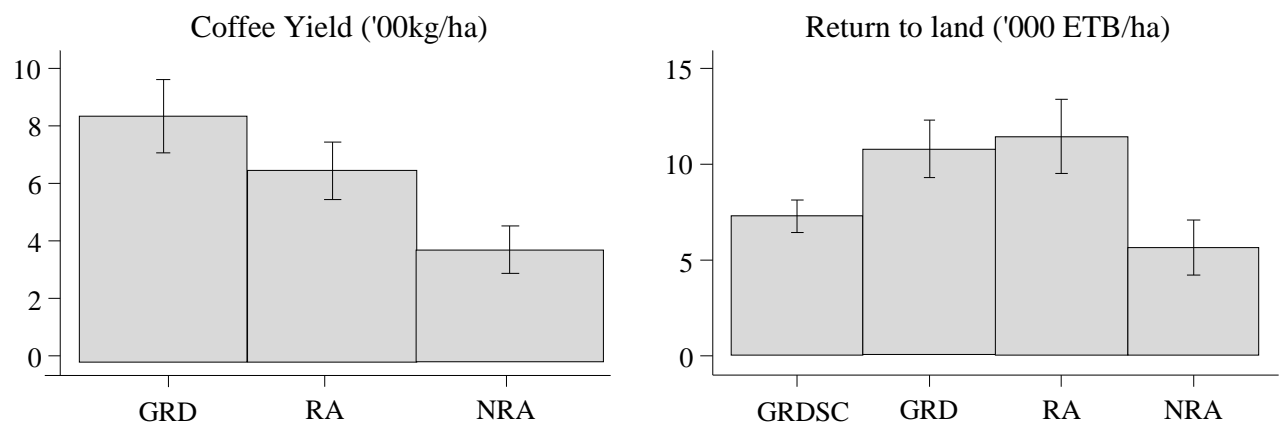

Return to labor ('00 ETB/MD)
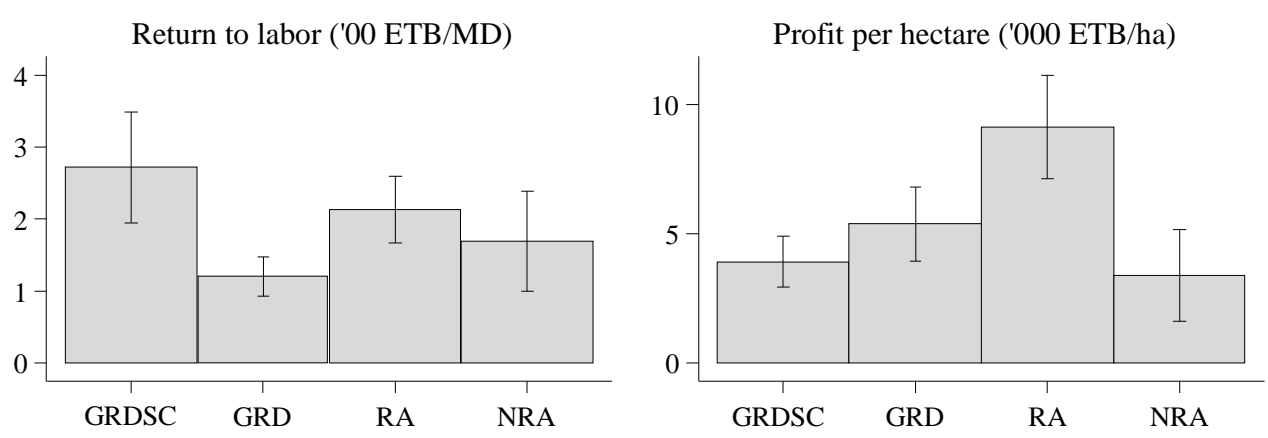

Figure 2: Coffee yields, return to land, return to labor and profits for garden plots with coffee and seasonal crops (GRDSC), garden coffee plots (GRD), Rainforest Alliance semi-forest coffee plots (RA), and non-certified semi-forest coffee plots (NRA). Error bars represent 95\% confidence interval. Source: Authors' calculation based on household survey data

Table 4 summarizes the estimated parameters on RA-certified and non-certified semiforest plots, in comparison with garden coffee as baseline category, from the OLS and FE 
estimations specified in equation (1) to (3). The full regression results are reported in tables A1 to A3 in annex. The results show that after controlling for plot and household observable characteristics in the OLS model, coffee yield $(\mathrm{p}=0.01)$ and return to land $(\mathrm{p}=0.09)$ are significantly lower in non-certified semi-forest coffee plots than in garden coffee plots. But there are no significant differences in return to labor and profits between garden coffee plots and non-certified semi-forest coffee plots. When controlling for household-level unobserved effects in the FE models, no significant differences between garden coffee plots and noncertified semi-forest plots remain for any outcome indicators. The absence of statistical significance and the differences in parameter estimates on coffee yield and return to land in the FE models relate to further reduction in unobserved heterogeneity bias and to using subsamples of the full sample. The OLS point estimate for non-certified semi-forest plots on coffee yield is $-181 \mathrm{~kg} / \mathrm{ha}$, which implies a difference in yield of $26 \%$ of the sample average between less intensified semi-forest and more intensified garden coffee systems. Similarly, the OLS point estimate for non-certified semi-forest coffee on return to land is $-2,085 \mathrm{ETB} / \mathrm{ha}$, which implies a difference in return to land of $24 \%$ of the sample average between less intensified semi-forest and more intensified garden coffee systems.

We find no significant differences in coffee yield between RA-certified semi-forest coffee plots and garden coffee plots. We find significantly higher returns to labor $(p=0.06)$ and profits $(\mathrm{p}=0.08)$ on RA-certified semi-forest coffee plots than on garden coffee plots, when observable plot and household characteristics are controlled for; and significantly higher returns to land $(\mathrm{p}=0.05)$ and labor $(\mathrm{p}=0.03)$, and profits $(\mathrm{p}<0.01)$ when household fixed effects are controlled for. The magnitude and significance level of the estimated effects are stronger in the FE model than in the OLS model, which might indicate a problem of unobserved heterogeneity bias and underestimated effects in the OLS models. The estimated effects are economically important. Returns to land on RA-certified semi-forest plots are 1,379 to 3,184 ETB/ha higher than on garden coffee plots, which implies a difference in return to land of 16 to $36 \%$ of the sample average. Returns to labor are 57 to 97 ETB/man-day higher on RA-certified semi-forest plots than on garden coffee plots, which implies a difference in return to labor of 30 to $52 \%$ of the sample average. Profits are 2,402 to 6,763 ETB/ha higher on RA-certified semi-forest plots than on garden coffee plots, which implies a difference in profit of 47 to $132 \%$ of the sample average. Further, post-estimation F-tests reveal that for return to land, return to labor and profits, estimated effects are significantly higher for RA-certified semi-forest plots than for noncertified semi-forest plots, which implies a positive effect on the returns to and profitability of RA certification. 
Table 4: Summary of estimated effects for Rainforest Alliance certified semi-forest coffee (RA) and non-certified semi-forest coffee (NRA), in comparison with garden coffee, from OLS and fixed effects estimations.

\begin{tabular}{lcccccccc}
\hline & \multicolumn{3}{c}{ OLS models } & \multicolumn{3}{c}{ Fixed effects models } \\
& \multicolumn{2}{c}{ NRA } & \multicolumn{2}{c}{ RA } & \multicolumn{2}{c}{ NRA } & \multicolumn{2}{c}{ RA } \\
\hline Coffee yield & $-180.5^{*}$ & $(73.2)$ & -80.26 & $(74.1)$ & -179.4 & $(130.2)$ & 34.8 & $(102.1)$ \\
Return to land & $-2,085^{*}$ & $(1,243)$ & $1,379^{\mathrm{b}}$ & $(1,276)$ & $-1,033$ & $(2,313)$ & $3,184^{* *}$ & $(1,582)$ \\
Return to labor & -11.7 & $(36.4)$ & $57.4^{* a}$ & $(30.2)$ & -16.9 & $(25.5)$ & $96.5^{* *}$ & $(42.4)$ \\
Profit per ha & -901.98 & $(1,477)$ & $2,474^{* \mathrm{~b}}$ & $(1,234)$ & 2,791 & $(2,622)$ & $6,763^{* * *}$ & $(1,902)$ \\
\hline
\end{tabular}

Standard errors in italic in parentheses. Significant effects in the regression models are indicated with ${ }^{*} p<0.1,{ }^{* *}$ $\mathrm{p}<0.05,{ }^{* * *} \mathrm{p}<0.01$. Significant differences from a post-estimation F-tests comparing the OLS parameters for RA and NRA are indicated with ${ }^{\mathrm{a}} \mathrm{p}<0.1$ and ${ }^{\mathrm{b}} \mathrm{p}<0.05$. Source: Authors' estimation from own survey data

Some other factors contribute to explaining differences in coffee yields, return to land, return to labor and profits as well (tables $\mathrm{A} 1$ to $\mathrm{A} 3$ in appendix). We find productivity to be higher on smaller coffee plots while the age of the coffee shrubs has a positive but decreasing effect on productivity and profits. Also altitude and slope of the plot matter while the soil type does not influence yields and productivity, which is likely due to the use of a broad soil classification and low variability in soil type within the study area. Education is found to be positively related to productivity, which is in line with expectations. Also livestock ownership is positively related to coffee yields, which is explained by the use of manure for fertilization of coffee plots.

\section{Discussion}

The results imply that more intensified garden coffee plots bring about higher yields and returns to land than less intensified semi-forest coffee plots but that there are no differences in return to labor and profits between the more and less intensified coffee system. This is in line with economic expectations and the specificity of the research area. The process of coffee intensification in the research area, driven by increasing land scarcity, is a process of increasing labor intensity with remaining low capital intensity, and replacing land for labor through increased shrub density and increased coffee management (tillage, organic fertilization, weeding, disease and pest control). With such a labor-intensive and land-saving transformation, one expects the productivity and returns to land to increase but not necessarily the productivity and returns to labor. Our findings from a static comparison between less and more intensified coffee systems point in this direction. The results from Ethiopia contradict earlier findings from Indonesia and Mexico, where coffee intensification is observed to have no impact on coffee yields or revenue (Gordon et al. 2007; Romero-Alvarado et al., 2002; Peeters et al., 2003; 
Philpott et al., 2008). The divergent findings are most likely related to the specificity of the research area and the coffee intensification process. While coffee intensification in Ethiopia is mostly labor-intensive and replaces land for labor; the process of coffee intensification in middle-income countries like Indonesia and Mexico is likely more capital-intensive and replaces land (and labor) for capital. Our results only partially support the underlying assumptions in many ecological studies that coffee intensification is associated with higher economic benefits and profits, which calls for more attention and nuance in such assumptions.

The results show that with Rainforest Alliance (RA) certification semi-forest coffee plots are slightly more intensively cultivated (with more coffee shrubs but less coffee management) than non-certified semi-forest plots but less intensively than garden coffee plots; and result in higher returns to labor and capital, and larger profits than non-certified semi-forest coffee plots as well as garden coffee plots. These higher returns are mainly associated with a price effect and not with a yield effect. Our results for Ethiopia are to some extent contradicting findings in the literature. Perfecto et al. (2005) conclude that RA coffee certification in Mexico has no impact because the price premium does not compensate for lower yields in shade coffee systems. For Nicaragua, Ruben and Zuniga (2011) find that RA certification reduces poverty and enhances household income, but that these effects mainly stem from a positive yield effect. Again, this points to effects of certification being case-study specific. First, differences in yields between more labor-intensive garden coffee and less labor-intensive semi-forest coffee are small in our research area, and therefore more easily compensated by a price premium related to certification. These yield difference might be more pronounced, and less easily compensated by a price premium, in more capital-intensive coffee systems. Second, in Ethiopia RA-certified coffee production is supported by JICA and OFWE and RA-certified coffee directly supplied to OFWE, where it is processed and directly exported; while non-certified coffee is sold through private traders or local cooperatives, cooperative unions and the Ethiopian Commodity Exchange (Mitiku et al., 2017). This support makes the RA-certified coffee supply chain shorter and more efficient and results in a more direct transmission of the price premium to producers. In other systems, a price premium may not trickle down completely and be absorbed along the supply chain.

Our findings that economic returns and profits are substantially larger on RA-certified semi-forest coffee plots than on garden coffee plots, imply that certification of semi-forest coffee might create the right incentives towards farmers for land-sharing between less intensive coffee production and semi-natural forest conservation. However, the fact that the economic benefits from RA-certification only come from a price effect, and not from a yield effect, calls 
for caution. This implies that the demand for certified coffee in the international market is a crucial determining factor for RA-certification of semi-forest coffee to remain beneficial for producers. While production of certified coffee is increasing - RA certification accounts for $3.6 \%$ of the global coffee area, and total coffee certification for 38\% (Lernoud et al., 2016) demand for certified coffee is not. It is has been estimated that only $25 \%$ of coffee produced under a certificate is effectively sold as certified coffee and that this is decreasing (Potts et al., 2014). Also efficient supply chains in which a price premium for certified coffee is effectively transmitted to producers is a pre-condition for sustained economic benefits from certification of less intensive semi-forest coffee systems.

Further, the results point out that the return to land from seasonal crop production is lower than the return to land from coffee production, while the return to labor is higher. This is in line with a food-first-strategy (rather than a profit-maximizing strategy) of local households (Tadesse et al., 2014). Finally, our results imply that plot-level heterogeneity is important to take into account when studying the impact of coffee certification. Many economic studies on the impact of private sustainability standards, in the coffee sector or in other sectors, do not account for differences in production system, agro-ecological characteristics and other plotlevel characteristics. Correlation between the location of plots or the age of coffee shrubs on the one hand and certification on the other hand is likely and may lead to bias in estimated effects if plot heterogeneity is not controlled for.

\section{Conclusion}

In this study, we use detailed household- and plot-level data and OLS and fixed effects models to statically compare the economic benefits of more intensified garden coffee systems and less intensive, Rainforest Alliance certified and non-certified, semi-forest coffee systems. We find that garden coffee plots are especially more labor-intensive and bring about higher yields and returns to land than less labor-intensive semi-forest coffee plots. In addition, we find that Rainforest Alliance certification of semi-forest coffee leads to higher returns to land and labor, and profits than non-certified semi-forest and garden coffee, mainly by guaranteeing farmers a better price and not by improving yields. These findings imply that in southwestern Ethiopia coffee certification can support incentives towards farmers for land-sharing between less intensified coffee production and the conservation of semi-natural forest. Our results imply that participatory forest management policies in southwestern Ethiopia can rely on Rainforest Alliance coffee certification schemes to protect semi-forest coffee systems form further 
intensification at a low opportunity cost. However, this is conditional on international demand for certified coffee and consumer willingness to pay a price premium for certified coffee as well as on efficiency in coffee supply chains to transmit a price premium to producers.

A limitation of our study is the focus on the economic dimension of coffee intensification from semi-forest to garden coffee, and coffee certification; without addressing environmental and ecological outcomes. Substantial evidence is available on the ecological benefits of forest coffee production systems or the consequences of coffee intensification in terms of loss in ecosystem services, biodiversity loss in particular. There is less evidence on the ecological consequences of coffee certification while some certificates such as RA focus specifically on biodiversity conservation. There is scope for ecological and multidisciplinary studies on the sustainability implications of coffee certification. In addition, our study is a static comparison of more intensified garden coffee systems and less intensified semi-forest coffee systems. Limitations thereby are that we focus on a very narrow gradient of intensity of coffee management, that we do not take into account spared less disturbed forest, that we do not capture dynamic effects of coffee intensification over time, and that likely not all costs and benefits of coffee intensification are accounted for. These shortcomings prevent us from drawing stronger conclusions on the sustainability of land-sharing versus land-sparing in our research area. Yet, these shortcomings do not jeopardize the main conclusion that Rainforest Allliance certification can compensate for lower economic returns from less intensive coffee cultivation and create incentives for land-sharing in semi-forest coffee systems. 


\section{References}

Aerts, R., Berecha, G., Gijbels, P., Hundera, K., Van Glabeke, S., Vandepitte, K., Muys, B., RoldánRuiz, I. \& Honnay, O. 2013. Genetic variation and risks of introgression in the wild Coffea arabica gene pool in south-western Ethiopian montane rainforests. Evolutionary Applications, 6, 243-252.

Bacon, C. 2005. Confronting the Coffee Crisis: Can Fair Trade, Organic, and Specialty Coffees Reduce Small-Scale Farmer Vulnerability in Northern Nicaragua? World Development, 33, $497-$ 511.

Barrett, C. B., Christine, M. M., Oloro, V. M. \& Joeli, B. 2004. Better Technology, Better Plots, or Better Farmers? Identifying Changes in Productivity and Risk among Malagasy Rice Farmers. American Journal of Agricultural Economics, 86, 869-888.

Bekessy, S. A., Wintle, B. A., Lindenmayer, D. B., McCarthy, M. A., Colyvan, M., Burgman, M. A. \& Possingham, H. P. 2010. The biodiversity bank cannot be a lending bank. Conservation Letters, 3, 151-158.

Dressler, W., de Koning, J., Montefrio, M. \& Firn, J. 2016. Land sharing not sparing in the "green economy": The role of livelihood bricolage in conservation and development in the Philippines. Geoforum, 76, 75-89.

Francom, M. G. \& Tefera, A. 2016. Ethiopia: Coffee Annual, Coffee Production and Exports Remain Steady. Addis Ababa: USAD Foreign Agriculture Service.

Getahun, K., Van Rompaey, A., Van Turnhout, P. \& Poesen, J. 2013. Factors controlling patterns of deforestation in moist evergreen Afromontane forests of Southwest Ethiopia. Forest Ecology and Management, 304, 171-181.

Gole, T. W., Borsch, T., Denich, M. \& Teketay, D. 2008. Floristic composition and environmental factors characterizing coffee forests in southwest Ethiopia. Forest Ecology and Management, 255, 2138-2150.

Gordon, C., Manson, R., Sundberg, J. \& Cruz-Angón, A. 2007. Biodiversity, profitability, and vegetation structure in a Mexican coffee agroecosystem. Agriculture, Ecosystems \& Environment, 118, 256-266.

Green, R. E., Cornell, S. J., Scharlemann, J. P. W. \& Balmford, A. 2005. Farming and the Fate of Wild Nature. Science, 307, 550-555.

Hardt, E., Borgomeo, E., dos Santos, R. F., Pinto, L. F. G., Metzger, J. P. \& Sparovek, G. 2015. Does certification improve biodiversity conservation in Brazilian coffee farms? Forest Ecology and Management, 357, 181-194.

Hundera, K., Aerts, R., Beenhouwer, M. D., Overtveld, K. V., Helsen, K., Muys, B. \& Honnay, O. 2013a. Both forest fragmentation and coffee cultivation negatively affect epiphytic orchid diversity in Ethiopian moist evergreen Afromontane forests. Biological Conservation, 159, 285-291. 
Hundera, K., Aerts, R., Fontaine, A., Mechelen, M., Gijbels, P., Honnay, O. \& Muys, B. 2013b. Effects of Coffee Management Intensity on Composition, Structure, and Regeneration Status of Ethiopian Moist Evergreen Afromontane Forests. Environmental Management, 51, 801-809.

Hylander, K., Nemomissa, S., Delrue, J. \& Enkosa, W. 2013. Effects of Coffee Management on Deforestation Rates and Forest Integrity. Conservation Biology, 27, 1031-1040.

International Coffee Organization. 2017. Available: http://www.ico.org/new historical.asp [Accessed 28 May 2017].

Kremen, C. 2015. Reframing the land-sparing/land-sharing debate for biodiversity conservation. Annals of the New York Academy of Sciences, 1355, 52-76.

Kremen, C. \& Miles, A. 2012. Ecosystem Services in Biologically Diversified versus Conventional Farming Systems: Benefits, Externalities, and Trade-Offs. Ecology and Society, 17.

Kufa, T. 2012. Recent coffee research development in Ethiopia. Prensented at Ethiopian Coffee Export Conference: Strengthening the Legacy of Our Coffee. Hilton, Addis Ababa.

Law, E. A., Meijaard, E., Bryan, B. A., Mallawaarachchi, T., Koh, L. P. \& Wilson, K. A. 2015. Better land-use allocation outperforms land sparing and land sharing approaches to conservation in Central Kalimantan, Indonesia. Biological Conservation, 186, 276-286.

Lee, J. S. H., Garcia-Ulloa, J., Ghazoul, J., Obidzinski, K. \& Koh, L. P. 2014. Modelling environmental and socio-economic trade-offs associated with land-sparing and land-sharing approaches to oil palm expansion. Journal of Applied Ecology, 51, 1366-1377.

Lernoud, J., Potts, J., Sampson, G., Voora, V., Willer, H. \& Wozniak, J. The State of Sustainable Markets-Statistics and Emerging Trends 2015. International Trade Center (2016).

Lusiana, B., van Noordwijk, M. \& Cadisch, G. 2012. Land sparing or sharing? Exploring livestock fodder options in combination with land use zoning and consequences for livelihoods and net carbon stocks using the FALLOW model. Agriculture, Ecosystems \& Environment, 159, 145-160.

Minten, B., Randrianarison, L. \& Swinnen, J. 2007. Spillovers from high-value agriculture for exports on land use in developing countries: evidence from Madagascar. Agricultural Economics, 37, 265275.

Minten, B., Tamiru, S., Kuma, T. \& Nyarko, Y. 2014. Structure and Performance of Ethiopia's Coffee Export Sector. Working Paper 66. Addis Ababa: International Food Policy Research Institute (IFPRI).

Mitiku, F., de Mey, Y., Nyssen, J. \& Maertens, M. 2017. Do Private Sustainability Standards Contribute to Income Growth and Poverty Alleviation? A Comparison of Different Coffee Certification Schemes in Ethiopia. Sustainability, 9, 246.

Noponen, M. R. A., Haggar, J. P., Edwards-Jones, G. \& Healey, J. R. 2013. Intensification of coffee systems can increase the effectiveness of REDD mechanisms. Agricultural Systems, 119, 1-9. 
Peeters, L. Y. K., Soto-Pinto, L., Perales, H., Montoya, G. \& Ishiki, M. 2003. Coffee production, timber, and firewood in traditional and Inga-shaded plantations in Southern Mexico. Agriculture, Ecosystems \& Environment, 95, 481-493.

Perfecto, I., Vandermeer, J., Mas, A. \& Pinto, L. S. 2005. Biodiversity, yield, and shade coffee certification. Ecological Economics, 54, 435-446.

Phalan, B., Green, R. \& Balmford, A. 2014. Closing yield gaps: perils and possibilities for biodiversity conservation. Philosophical Transactions of the Royal Society B: Biological Sciences, 369.

Phalan, B., Onial, M., Balmford, A. \& Green, R. E. 2011. Reconciling Food Production and Biodiversity Conservation: Land Sharing and Land Sparing Compared. Science, 333, 1289-1291.

Philpott, S., Bichier, P., Rice, R. \& Greenberg, R. 2008. Biodiversity conservation, yield, and alternative products in coffee agroecosystems in Sumatra, Indonesia. Biodiversity and Conservation, 17, 1805-1820.

Pinto, L. F. G., Gardner, T., McDermott, C. L. \& Ayub, K. O. L. 2014. Group certification supports an increase in the diversity of sustainable agriculture network-rainforest alliance certified coffee producers in Brazil. Ecological Economics, 107, 59-64.

Potts, J., Lynch, M., Wilkings, A., Huppé, G., Cunningham, M. \& Voora, V. 2014. The state of sustainability initiatives review 2014: Standards and the green economy. International Institute for Sustainable Development (IISD) and the International Institute for Environment and Development (IIED).

Rainforest Alliance. 2015a. Rainforest Alliance, Certification, Verification and Validation Services [Online]. Available: http://www.rainforest-alliance.org/certification-verification [Accessed on 04 January 2016].

Rainforest Alliance. 2015b. SAN/Rainforest Alliance Impacts Report. Evaluating the Effects of the SAN/Rainforest Alliance Certification System on Farms, People, and the Environment [Online]. Available: http://www.rainforestalliance.org/sites/default/files/publication/pdf/SAN_RA_Impacts_Report.pdf [Accessed on 04 January 2016].

Reichhuber, A. \& Requate, T. 2012. Alternative use systems for the remaining Ethiopian cloud forest and the role of Arabica coffee - A cost-benefit analysis. Ecological Economics, 75, 102-113.

Riera, O. \& Swinnen, J. 2016. Household level spillover effects from biofuels: Evidence from castor in Ethiopia. Food Policy, 59, 55-65.

Romero-Alvarado, Y., Soto-Pinto, L., García-Barrios, L. \& Barrera-Gaytán, J. F. 2002. Coffee yields and soil nutrients under the shades of Inga sp. vs. multiple species in Chiapas, Mexico. Agroforestry Systems, 54, 215-224.

Ruben, R. \& Zuniga, G. 2011. How standards compete: comparative impact of coffee certification schemes in Northern Nicaragua. Supply Chain Manag, 16, 98-109. 
Rueda, X., Thomas, N. E. \& Lambin, E. F. 2015. Eco-certification and coffee cultivation enhance tree cover and forest connectivity in the Colombian coffee landscapes. Regional Environmental Change, 15, 25-33.

Steffan-Dewenter, I., Kessler, M., Barkmann, J., Bos, M. M., Buchori, D., Erasmi, S., Faust, H., Gerold, G., Glenk, K., Gradstein, S. R., Guhardja, E., Harteveld, M., Hertel, D., Höhn, P., Kappas, M., Köhler, S., Leuschner, C., Maertens, M., Marggraf, R., Migge-Kleian, S., Mogea, J., Pitopang, R., Schaefer, M., Schwarze, S., Sporn, S. G., Steingrebe, A., Tjitrosoedirdjo, S. S., Tjitrosoemito, S., Twele, A., Weber, R., Woltmann, L., Zeller, M. \& Tscharntke, T. 2007. Tradeoffs between income, biodiversity, and ecosystem functioning during tropical rainforest conversion and agroforestry intensification. Proceedings of the National Academy of Sciences, 104, 4973-4978.

Stillmacher, T. \& Grote, U. 2011. Forest Coffee Certification in Ethiopia: Economic boon or ecological bane? ZEF working paper series 76 . Bonn.

Sustainable Agriculture Network. 2010. Sustainable Agriculture Standard [Online]. Available: http://www.san.ag/biblioteca/docs/SAN-S-1-4 Sustainable Agriculture Standard.pdf [Accessed 03 Jan 2017].

Tadesse, G., Zavaleta, E., Shennan, C. \& FitzSimmons, M. 2014. Policy and demographic factors shape deforestation patterns and socio-ecological processes in southwest Ethiopian coffee agroecosystems. Applied Geography, 54, 149-159.

Takahashi, R. \& Todo, Y. 2013. The impact of a shade coffee certification program on forest conservation: A case study from a wild coffee forest in Ethiopia. Journal of Environmental Management, 130, 48-54.

Takahashi, R. \& Todo, Y. 2014. The impact of a shade coffee certification program on forest conservation using remote sensing and household data. Environmental Impact Assessment Review, 44, 76-81.

Takahashi, R. \& Todo, Y. 2017. Coffee Certification and Forest Quality: Evidence from a Wild Coffee Forest in Ethiopia. World Development, 92, 158-166.

Tefera, A. \& Tefera, T. 2014. Ethiopia: Coffee Annual, Coffee Annual Report. ET 1402. Addis Ababa: USDA Foreign Agriculture Service.

Tegegne, H. K. 2017. Impact of deforestation on biodiversity, soil carbon stocks, soil quality, runoff and sediment yield at southwest Ethiopia's forest frontier. $\mathrm{PhD}$ thesis, Ghent University.

Tscharntke, T., Clough, Y., Wanger, T. C., Jackson, L., Motzke, I., Perfecto, I., Vandermeer, J. \& Whitbread, A. 2012. Global food security, biodiversity conservation and the future of agricultural intensification. Biological Conservation, 151, 53-59.

Wiersum, K. F., Gole, T. W., Gatzweiler, F., Volkmann, J., Bognetteau, E. \& Wirtu, O. 2008. Certification of Wild Coffee in Ethiopia: Experiences and Challenges. Forests, Trees and Livelihoods, 18, 9-21. 
Yoshii, C., Yamaura, Y., Soga, M., Shibuya, M. \& Nakamura, F. 2015. Comparable benefits of land sparing and sharing indicated by bird responses to stand-level plantation intensity in Hokkaido, northern Japan. Journal of Forest Research, 20, 167-174. 


\section{Appendix}

Table A1: Results from OLS regression models estimating the effects of Rainforest Alliance certified semi-forest coffee (RA) and non-certified semi-forest coffee (NRA) on coffee yield, return to land, return to labor, and profits from coffee production

\begin{tabular}{|c|c|c|c|c|c|c|c|c|}
\hline \multirow[b]{2}{*}{ RA semi-forest } & \multicolumn{2}{|c|}{ Coffee yield } & \multicolumn{2}{|c|}{ Return to land } & \multicolumn{2}{|c|}{ Return to labor } & \multicolumn{2}{|c|}{ Profit per ha } \\
\hline & -80.26 & $(74.06)$ & $1,379^{\mathrm{b}}$ & $(1,276)$ & $57.38^{* a}$ & $(30.21)$ & $2,474^{* b}$ & $(1,425)$ \\
\hline NRA semi-forest & $-180.5^{* *}$ & (73.22) & $-2,086^{*}$ & $(1,243)$ & -11.73 & $(36.40)$ & -902 & $(1,477)$ \\
\hline Coffee age & 0.98 & $(4.47)$ & 22.41 & (76.20) & $4.68^{* *}$ & $(2.23)$ & $123.9^{*}$ & (70.16) \\
\hline Coffee age 2 & -0.02 & $(0.05)$ & -0.42 & $(0.88)$ & $-0.06^{* *}$ & $(0.03)$ & $-1.41^{*}$ & $(0.83)$ \\
\hline Coffee area & $-170.1^{* * * *}$ & (31.12) & $-2,326^{* * *}$ & (466) & $53.87^{* * *}$ & (15.99) & $-957.8^{*}$ & (489) \\
\hline Coffee area2 & $12.71^{* * *}$ & $(3.40)$ & $157.6^{* * *}$ & (49.54) & $-5.08^{*}$ & $(2.73)$ & 58.59 & (44.36) \\
\hline Distance to coop & -0.02 & $(0.02)$ & -0.30 & $(0.36)$ & $-0.01^{* *}$ & $(0.01)$ & -0.05 & $(0.37)$ \\
\hline Distance to road & $-0.04^{* * *}$ & $(0.01)$ & $-0.65^{* * *}$ & $(0.15)$ & -0.00 & $(0.00)$ & $-0.36^{* * *}$ & $(0.12)$ \\
\hline Distance to river & 0.02 & $(0.02)$ & 0.17 & $(0.31)$ & $0.01^{*}$ & $(0.01)$ & 0.26 & $(0.33)$ \\
\hline Altitude & 0.17 & $(0.31)$ & -2.14 & $(5.08)$ & $-0.25^{* *}$ & $(0.12)$ & 3.55 & $(4.01)$ \\
\hline Lithic Leptosols & 51.97 & (160.6) & -625.4 & $(2,322)$ & -36.00 & $(66.58)$ & 1,653 & $(2,664)$ \\
\hline Slope & -1.72 & $(5.31)$ & 13.14 & (96.34) & $-5.43^{*}$ & (3.09) & 45.25 & $(90.63)$ \\
\hline Humic Nitisols & 3.71 & (109) & $-1,040$ & $(1,776)$ & -96.48 & (59.06) & 646.56 & $(1,865)$ \\
\hline Head's sex & -9.46 & (109.4) & $-1,547$ & $(1,610)$ & -25.93 & (37.07) & $-2,185$ & $(1,520)$ \\
\hline Head's age & -3.45 & $(2.21)$ & $-62.79^{*}$ & $(38.01)$ & $-2.13^{*}$ & (1.26) & $-77.4^{* *}$ & (32.66) \\
\hline Head education & $20.85^{* *}$ & $(9.85)$ & $370.7^{* *}$ & (178.6) & $6.35^{*}$ & (3.57) & $647.6^{* * *}$ & $(150.5)$ \\
\hline Total adult & $39.03^{*}$ & (20.32) & $611.3^{*}$ & (319) & -10.97 & (8.98) & 379.5 & $(299.2)$ \\
\hline Total dependents & -15.42 & (18.26) & -117.6 & (299.3) & $-12.83^{* *}$ & $(6.43)$ & -471.24 & $(252.7)$ \\
\hline Livestock (TLU) & 4.58 & $(7.21)$ & 24.19 & (109.8) & 1.98 & (3.01) & 161.3 & $(107.8)$ \\
\hline Social capital & 0.73 & $(0.46)$ & 10.80 & $(7.15)$ & 0.03 & $(0.11)$ & $17.45^{* *}$ & (7.17) \\
\hline Constant & 595 & (588) & $17,025^{*}$ & $(9,663)$ & $778.1^{* *}$ & (305.8) & $-2,270$ & $(8,380)$ \\
\hline $\mathrm{N}$ & 758 & & 758 & & 758 & & 758 & \\
\hline F-test & 7.72 & & 8.86 & & 3.20 & & 6.11 & \\
\hline Prob $>F$ & 0.00 & & 0.00 & & 0.00 & & 0.00 & \\
\hline $\mathrm{R}^{2}$ & 0.14 & & 0.11 & & 0.07 & & 0.11 & \\
\hline
\end{tabular}

Standard errors in parentheses. Significant effects in the regression models are indicated with ${ }^{*} \mathrm{p}<0.1,{ }^{* *} \mathrm{p}<0.05$, ${ }^{* * * *} \mathrm{p}<0.01$. Significant differences from a post-estimation F-tests comparing the OLS parameters for RA and NRA are indicated with ${ }^{\mathrm{a}} \mathrm{p}<0.1$ and ${ }^{\mathrm{b}} \mathrm{p}<0.05$. Source: Authors' estimation from own survey data 
Table A2: Results from fixed effects regression models estimating the effect of noncertified semi-forest coffee (NRA) on coffee yield, return to land and labor, and profit from coffee production

\begin{tabular}{lcccccccc}
\hline & \multicolumn{2}{c}{ Coffee yield } & \multicolumn{2}{c}{ Return to land } & \multicolumn{2}{c}{ Return to labor } & \multicolumn{2}{c}{ Profit per ha } \\
\hline NRA semi-forest & -179.4 & $(130.2)$ & $-1,033$ & $(2,313)$ & -16.95 & $(25.47)$ & 2,791 & $(2,622)$ \\
Coffee age & 0.28 & $(14.18)$ & 158.8 & $(222.3)$ & -3.40 & $(2.70)$ & 148.2 & $(216.7)$ \\
Coffee age2 & 0.07 & $(0.13)$ & 0.32 & $(1.98)$ & $0.05^{* *}$ & $(0.02)$ & -0.78 & $(1.85)$ \\
Coffee area & -106.8 & $(86.08)$ & $-16,189$ & $(1,414)$ & 24.84 & $(20.51)$ & $-1,572$ & $(1,201)$ \\
Coffee area2 & 6.30 & $(12.06)$ & 53.14 & $(169.9)$ & -3.39 & $(2.69)$ & 62.68 & $(142.9)$ \\
Distance to coop & 0.07 & $(0.08)$ & 1.14 & $(1.29)$ & 0.01 & $(0.02)$ & $2.14^{* *}$ & $(1.05)$ \\
Distance to road & $-0.25^{*}$ & $(0.13)$ & $-4.48^{*}$ & $(2.31)$ & -0.04 & $(0.03)$ & -3.53 & $(2.35)$ \\
Distance to river & $-0.27^{*}$ & $(0.14)$ & $-6.14^{*}$ & $(3.21)$ & -0.01 & $(0.02)$ & $-2.52^{* *}$ & $(1.23)$ \\
Altitude & 0.84 & $(1.11)$ & 7.51 & $(14.75)$ & -0.23 & $(0.14)$ & 5.33 & $(15.28)$ \\
Slope & -39.61 & $(34.73)$ & -732.9 & $(803.8)$ & -5.59 & $(4.31)$ & 71.2 & $(193.2)$ \\
Humic Nitisols & $522.2^{* *}$ & $(239.9)$ & -116.9 & $(6,088)$ & 232.5 & $(177.1)$ & $10,442^{*}$ & $(5,527)$ \\
Constant & 94.94 & $(1,773)$ & 22,628 & $(32,338)$ & 468.1 & $(360.7)$ & $-8,965$ & $(34,363)$ \\
\hline $\mathrm{N}$ & 132 & & 132 & & 132 & & 132 & \\
F-test & 26.55 & & 4.38 & & 1.22 & & 2.89 & \\
Prob>F & 0.00 & & 0.00 & & 0.29 & & 0.00 & \\
$\mathrm{R}^{2}$ & 0.24 & & 0.14 & & 0.09 & & 0.12 & \\
\hline
\end{tabular}

Standard errors in parentheses. Significant effects in the regression models are indicated with ${ }^{*} \mathrm{p}<0.1,{ }^{* *} \mathrm{p}<0.05$, ${ }^{* * *} \mathrm{p}<0.01$. Source: Authors' estimation from own survey data 
Table A3: Results from fixed effects regression models estimating the effect of Rainforest Alliance certified semi-forest coffee (RA) on coffee yield, return to land and labor, and profit from coffee production

\begin{tabular}{|c|c|c|c|c|c|c|c|c|}
\hline \multirow[b]{2}{*}{ RA semi-forest } & \multicolumn{2}{|c|}{ Coffee yield } & \multicolumn{2}{|c|}{ Return to land } & \multicolumn{2}{|c|}{ Return to labor } & \multicolumn{2}{|c|}{ Profit per ha } \\
\hline & 34.87 & $(102.1)$ & $3,184^{* * *}$ & $(1,582)$ & $96.54^{* * *}$ & (42.38) & $6,763^{* * *}$ & $(1,902)$ \\
\hline Coffee age & 7.43 & (11.18) & 50.21 & $(174.2)$ & -0.13 & $(3.86)$ & 58.86 & (145.7) \\
\hline Coffee age 2 & -0.11 & $(0.13)$ & -0.85 & $(1.95)$ & 0.01 & $(0.05)$ & -0.45 & $(1.48)$ \\
\hline Coffee area & $-395.8^{* * *}$ & $(115.6)$ & $-6,565^{* * *}$ & $(2,099)$ & -0.30 & $(47.68)$ & $-4,488^{*}$ & $(2,299)$ \\
\hline Coffee area2 & $67.47^{* *}$ & $(27.5)$ & $1,071^{* *}$ & $(451)$ & $55.09^{* * *}$ & (18.38) & $786.5^{*}$ & (464.7) \\
\hline Distance to coop & $-0.14^{*}$ & $(0.08)$ & -1.23 & (1.17) & -0.06 & $(0.05)$ & -0.47 & $(1.31)$ \\
\hline Distance to road & 0.03 & $(0.16)$ & 0.42 & $(2.98)$ & 0.04 & $(0.07)$ & 0.98 & $(3.11)$ \\
\hline Distance to river & 0.17 & $(0.13)$ & 1.19 & $(2.09)$ & 0.04 & $(0.08)$ & -1.39 & $(2.22)$ \\
\hline Altitude & -1.24 & $(0.90)$ & -24.16 & $(16.51)$ & $-0.89^{*}$ & $(0.45)$ & -21.53 & $(15.16)$ \\
\hline Humic Alisols & 67.40 & (322.9) & $-1,717$ & $(6,879)$ & -59.51 & (266.9) & $-1,959$ & $(7,366)$ \\
\hline Slope & -1.03 & $(10.45)$ & 142.6 & $(224.7)$ & -2.26 & $(4.38)$ & 118.7 & $(210.5)$ \\
\hline Constant & $2,721^{*}$ & $(1,59)$ & $52,947^{*}$ & $(29,137)$ & $1,656^{* *}$ & (688.1) & $48,299^{*}$ & $(2,687)$ \\
\hline $\mathrm{N}$ & 163 & & 163 & & 163 & & 163 & \\
\hline F-test & 2.42 & & 1.76 & & 5.09 & & 2.85 & \\
\hline Prob $>F$ & 0.02 & & 0.09 & & 0.00 & & 0.01 & \\
\hline $\mathrm{R}^{2}$ & 0.21 & & 0.19 & & 0.43 & & 0.21 & \\
\hline
\end{tabular}

Standard errors in parentheses. Significant effects in the regression models are indicated with ${ }^{*} \mathrm{p}<0.1,{ }^{* *} \mathrm{p}<0.05$, ${ }^{* * *} \mathrm{p}<0.01$. Source: Authors' estimation from own survey data 
Table A4: Summary of the criteria used to inspect Rainforest Alliance certified forest coffee in southwestern Ethiopia. The criteria are organized and implemented based on SAN standard 2010, version 4 (Sustainable Agriculture Network, 2010). Source: summarized from Internal Inspection manual of the study area.

\begin{tabular}{|c|c|c|c|c|}
\hline Principles & $\begin{array}{l}\text { Total \# of } \\
\text { Criteria }\end{array}$ & $\begin{array}{l}\text { Order of } \\
\text { criteria in the } \\
\text { principle }\end{array}$ & Selected and applied criteria for RA coffee Internal Control system in Southwestern Ethiopia & $\begin{array}{l}\text { Importance } \\
\text { of the criteria }\end{array}$ \\
\hline $\begin{array}{l}\text { 1. Social and Environmental management } \\
\text { system }\end{array}$ & 11 & 1.10 & $\begin{array}{l}\text { Product Handling Procedures } \\
\text { Forest coffee is separately dried and stored from garden coffee, and is not mixed with coffee from other farmers }\end{array}$ & MUST \\
\hline \multirow[t]{3}{*}{ 2. Ecosystem conservation } & \multirow[t]{3}{*}{9} & 2.2 & NO expansion of forest coffee into natural forests & MUST \\
\hline & & 2.6 & Maintain natural vegetation along water bodies (e.g. streams and springs) & \\
\hline & & 2.8 & The forest canopy has more than two layers with higher than $40 \%$ shade cover & \\
\hline \multirow[t]{2}{*}{ 3. Wild life protection } & \multirow[t]{2}{*}{6} & 3.2 & NO cutting of indigenous tree to provide habitat for wild life & MUST \\
\hline & & 3.3 & NO hunting, capturing and trafficking wild animals & \\
\hline \multirow[t]{2}{*}{ 4. Water conservation } & \multirow[t]{2}{*}{9} & 4.5 & NO direct discharge of wastewater into natural water bodies & MUST \\
\hline & & 4.7 & NO depositing any solid wastes into natural water bodies & MUST \\
\hline \multirow{7}{*}{$\begin{array}{l}\text { 5. Fair Treatment and good working condition } \\
\text { for employees }\end{array}$} & \multirow[t]{7}{*}{20} & & Working conditions & \\
\hline & & 5.9 & $\begin{array}{l}\text { For children of the farm under the age of } 15, \text { physical safety is secured and educational obligations are not } \\
\text { interfered }\end{array}$ & MUST \\
\hline & & 5.18 & Had Internal Control System (ICS) training sessions from WaBUB Internal Inspection Team (WIIT) & \\
\hline & & & If the farm hire workers & \\
\hline & & $5.4,5.14$ & $\begin{array}{l}\text { Pre-arrangement of wages and other working conditions, e.g. the provision of housing, which are not less than the } \\
\text { standard of the area, upon the consensus with the workers }\end{array}$ & MUST \\
\hline & & 5.8 & NO hiring of worker under the age of 15 & MUST \\
\hline & & 5.10 & NO forced labor & MUST \\
\hline \multirow[t]{2}{*}{ 6. Occupational Health and safety program } & \multirow[t]{2}{*}{20} & 6.1 & Have an occupational health and safety programme to minimize occupational risks & \\
\hline & & $6.18,6.19$ & Have measures and equipment to respond to potential natural and human emergencies & \\
\hline 7. Community relations & 6 & & No criteria from this principle is indicated in study area & \\
\hline \multirow[t]{2}{*}{ 8. Integrated Crop Management } & \multirow[t]{2}{*}{9} & 8.1 & Have an integrated pest-management practices for minimizing agrochemical uses & \\
\hline & & 8.4 & $\begin{array}{l}\text { NO use and storage of banned agrochemicals in the farm } \\
\text { (Banned agrochemicals: Aldrin, DDT, Dieldrin, Heptachlor, Malathion, etc.) }\end{array}$ & MUST \\
\hline \multirow[t]{2}{*}{ 9. Soil Management and conservation } & \multirow[t]{2}{*}{5} & 9.1 & Measures to prevent or reduce soil erosion are taken & \\
\hline & & 9.2 & Have soil or crop fertilization programmes & \\
\hline \multirow[t]{2}{*}{ 10. Integrated waste management } & \multirow[t]{2}{*}{6} & 10.1 & Have an integrated domestic waste management programme & \\
\hline & & 10.5 & Have proper waste handling (place waste receptacles, collect and dump them regularly) & \\
\hline
\end{tabular}

